\title{
Um olhar para a seleção de textos e para a experiência em Língua Portuguesa e Literatura: por uma educação linguística e literária antirracista
}

Kedilen Dutra*

\begin{abstract}
Resumo:
O presente trabalho tem como objetivo problematizar a seleção de textos das aulas de Língua Portuguesa e Literatura do Ensino Fundamental, baseando-se nos pressupostos da Educação das Relações Étnico-Raciais (ERER), e tematizar a leitura literária pelo viés da experiência dos sujeitos históricos em sociedade. Para tanto, em um primeiro momento, discutimos algumas concepções a respeito da prática da ERER. Em seguida, tratamos da seleção de textos como etapa primordial na construção de um projeto de ensino-aprendizagem. Então, a partir do arcabouço teórico explorado, propomos uma seleção de textos apresentada por meio de tarefas de leitura. Finalmente, entendemos que a seleção de textos e a leitura entendida como uma experiência a ser compartilhada em sala de aula é uma possibilidade de concretização de uma educação linguística e literária antirracista.
\end{abstract}

\section{Palavras-chave:}

ERER. Seleção de textos. Educação linguística e literária antirracista.

\section{Resumen:}

El presente trabajo tiene como objetivo problematizar la selección de textos de las clases de Portugués y Literatura de la enseñanza primaria, basándose en los presupuestos de la Educación de las Relaciones Étnico Raciales (ERER), y tematizar la lectura literaria desde el sesgo de la experiencia de los sujetos históricos en sociedad. Para eso, en un primer momento, discutimos algunas concepciones a respeto de la práctica de la ERER. Enseguida, tratamos de la selección de textos como etapa primordial en la construcción de un proyecto de enseñanza y aprendizaje. Entonces, a partir del referencial teórico explorado, proponemos una selección de textos presentada a través de acti-

\footnotetext{
* Licencianda em Letras (Português/Francês) pela Universidade Federal do Rio Grande do Sul. E-mail: kedilen@hotmail.com. ORCID iD: https://orcid.org/0000-0002-0723-6505.

** Licenciando em Letras (Português/Espanhol) pela Universidade Federal do Rio Grande do Sul. E-mail:

thiago.martinsr2@gmail.com. ORCID iD: https://orcid.org/0000-0003-4137-3017.
} 
vidades de lectura. Por fin, entendemos que la selección de textos y la lectura comprendida como una experiencia a ser compartida en sala de clase es una clave interpretativa posible para la materialización de una educación lingüística y literaria antirracista.

\section{Palabras clave:}

ERER. Selección de textos. Educación lingüística y literaria antirracista.

\section{Introdução}

A sala de aula de Língua Portuguesa e Literatura (LPL) é um espaço de disputa de sentidos e interpelação de identidades. Isso não poderia ser diferente quando tratamos de questões tão intrínsecas ao homem - a exemplo da língua e da linguagem e suas diversas manifestações por meio de textos escritos e orais. Nesse sentido, Silva (2018), ao analisar produções acadêmicas que tematizam a Educação das Relações Étnico-Raciais (ERER), conclui que:

[...] o "silenciamento" é uma das ações, atitudes, estratégias adotadas pela escola brasileira para o enfrentamento do racismo. Dessa forma, de um lado professores não costumam intervir diante de conflitos que agridem crianças negras, em virtude de sua cor/raça, de outro, recomendam aos alunos negros, quando hostilizados por sua cor/raça, que ignorem, finjam que a agressão não é dirigida a eles. Os referidos artigos ressaltam que há pouca ou nenhuma intervenção das professoras em relação às situações de rejeição e discriminação vividas pelas crianças. A pouca ou a ausência de intervenção causa sofrimento junto às crianças negras, intensificando a baixa autoestima, além, de promover segregação e pouca convivência entre crianças negras e não negras. (SILVA, 2018, p. 131, grifos nossos).

Sendo assim, partimos do pressuposto que a ERER pretende construir uma sociedade mais justa, equânime e pautada por relações raciais que não se estruturem pelo racismo. Para isso, no componente curricular de LPL especificamente, é preciso "naturalizar" a inserção de textos de autoria não branca nas aulas e nos projetos de ensino. Logo, este artigo tem como objetivo problematizar a seleção de textos literários para a aula de LPL, com vistas à prática da ERER no Ensino Básico. Nosso argumento é o de que a inserção da leitura literária em sala de aula e o desenvolvimento de uma educação antirracista podem ser levadas à cabo se consideramos em nossa prática pedagógica a experiência dos indivíduos em sociedade e, assim, concretizarmos em LPL uma educação linguística e literária ${ }^{1}$ que seja antirracista. Dessarte,

[e]ntendemos por educação lingüística o conjunto de fatores socioculturais que, durante toda a existência de um indivíduo, lhe possibilitam adquirir, desenvolver e ampliar o conhecimento de/sobre sua língua materna, de/sobre outras línguas, sobre a linguagem de um modo mais geral e sobre todos os demais sistemas semióticos. (BAGNO; RANGEL, 2005, p. 63).

Para cumprir com nosso objetivo, propomos um projeto de ensino-aprendizagem do qual recortamos duas tarefas de leitura para a análise. Assim sendo, este trabalho organiza-se da seguinte maneira: seguido desta introdução, discutimos o campo da ERER e a legislação vigente; na sequência, tratamos da seleção de textos em LPL, bem como o ensino de Literatura pelo viés da experiência; posteriormente, a partir de uma seleção de textos que procura dar conta da diversidade das relações étnico-raciais, apresentamos uma 
proposta de projeto e tarefas, as quais analisamos, em um movimento teórico-prático, embasados nos pressupostos legais e teóricos abordados nas seções anteriores; por último, expomos nossas considerações finais.

\section{Situando o campo da ERER}

Este estudo tem como ponto de partida o disposto na Lei no 10.639 (BRASIL, 2003), um marco na legislação brasileira no que tange às ações governamentais para a correção das desigualdades étnico-raciais no Brasil. O texto altera o artigo 26-A da Lei no 9.394 (BRASIL, 1996), a conhecida Lei de Diretrizes e Bases da Educação Nacional (LDBEN), ao determinar a obrigatoriedade da temática "História e Cultura Afro-Brasileira” em toda a Educação Básica. A regulamentação de 2003 foi modificada cinco anos depois pela Lei $n^{\circ} 11.645$ (BRASIL,2008), quando se incluiu também o ensino da história e da cultura indígena como compromisso curricular das redes de ensino. Tal fato evidencia a relevância e a abrangência das lutas dos movimentos negros organizados para a construção de uma sociedade que não seja estruturada pelo racismo. Esse enfrentamento começa, invariavelmente, pela Educação.

Nesse sentido, a aplicação da ERER carrega consigo o histórico de coletividade, luta política por direitos e busca por uma repactuação das relações raciais no Brasil. Esses são princípios imperiosos que, se dispensados, implicam em uma prática pedagógica estéril, incapaz de cumprir com os objetivos que lhe foram colocados, atuando somente na reafirmação do racismo e na manutenção do status quo.

Tratamos a ERER, portanto, em um sentido radicalmente político, experiencial e emancipador, já que está pensada como uma intervenção direta na realidade permeada pelo racismo estrutural brasileiro, em suas diferentes instituições, por meio da Educação. Sendo assim,

[t]em-se, então, de enfrentar e recompor, no seio das famílias, no bairro onde se reside, nos estabelecimentos de ensino, nos ambientes de trabalho, em diferentes contextos, as relações diárias entre pessoas, distintos grupos sociais, étnico-raciais. Distintas maneiras de se relacionar, com respeito ou enfrentamentos, precisam ser examinadas, reconstruídas, sendo esta uma atitude política indispensável para a construção de uma sociedade realmente democrática. (SILVA, 2019, p. 17).

Por esse viés, entendemos que a lei por si só não basta. O sistema educacional brasileiro demonstra sua insuficiência na manutenção de crianças e jovens negros e negras frequentando assiduamente o ambiente escolar. Isso é o que Elisabete dos Santos, Eliane Pinto e Andréia Chirinéa (2018) demonstram e discutem a partir da análise de estudos demográficos brasileiros: há uma disparidade entre brancos e negros no acesso e na permanência no sistema de ensino que se agudiza quanto mais alto o nível de escolaridade. Esse apagamento físico e simbólico de negros e negras na educação brasileira é parte da naturalização da exclusão e da indiferença, ambas baseadas em um imaginário social que predefine lugares específicos de subalternidade para a população negra.

Esse aspecto tem feito parte do escopo de reflexão da professora Petronilha Beatriz Gonçalves e Silva (2007; 2018; 2019), que foi a relatora do Parecer CNE/CP nº 003/2004 (BRASIL, 2004), o qual estabelece as Diretrizes Curriculares Nacionais para a Educação das Relações Étnico-Raciais e para o Ensino de História e Cultura Afro-Brasileira e Africana. A docente emérita da Universidade Federal de São Carlos (UFSCar) coloca-nos uma provocação: a instituição escolar, de feições eurocêntricas e colonialistas, quando tomada em retrospecto, sempre serviu para a manutenção das desigualdades sociais e do racismo. Há um projeto de 
segregação e assimilação das minorias sociais ${ }^{2}$ por um suposto programa de nação civilizada que depende da chancela da instrução formal.

A escola, nesse contexto, incide em um “ocultamento da diversidade no Brasil” (SILVA, 2007, p. 498), o qual tem a "cultura do silenciamento" (SILVA, 2018, p. 134) como um artifício para dirimir quaisquer compreensões do racismo como um fenômeno estrutural, tratando-o somente como um fenômeno individual e isolado. Como efeito disso, a interdição de negras e negros, combinada à cultura do silenciamento, expressa-se também na produção e no intercâmbio de conhecimentos em sala de aula. Os currículos, os projetos de aprendizagem, as dinâmicas de aula e os conteúdos a serem estudados são todos pensados desde uma perspectiva eurocêntrica hegemônica concebida como clássica e, por isso, imutáveis. Estabelece-se, dessa maneira, o que Santos, Pinto e Chirinéa (2018, p. 494) caracterizam como a assunção de "critérios culturais e raciais para a produção e incorporação de conhecimento".

Em suma, a reversão desse quadro depende de um movimento real da sociedade em torno da supressão das desigualdades de raça, gênero, economia etc. A escola precisa contribuir de modo efetivo com esse processo, como uma instituição contestadora, capaz de elaborar criticamente saídas coletivas para o contexto de ofensivas racistas e antidemocráticas que vivemos. Nesse cenário, a Lei 10.639/03 e a ERER têm papel fundante:

A educação das relações étnico-raciais tem por alvo a formação de cidadãos, mulheres e homens empenhados em promover condições de igualdade no exercício de direitos sociais, políticos, econômicos, dos direitos de ser, viver, pensar, próprios aos diferentes pertencimentos étnico-raciais e sociais. Em outras palavras, persegue o objetivo precípuo de desencadear aprendizagens e ensinos em que se efetive participação no espaço público. Isto é, em que se formem homens e mulheres comprometidos com e na discussão de questões de interesse geral, sendo capazes de reconhecer e valorizar visões de mundo, experiências históricas, contribuições dos diferentes povos têm formado a nação, bem como o de negociar prioridades, coordenando diferentes interesses, propósitos, desejos, além de propor políticas que contemplem efetivamente a todos. (SILVA, 2007, p. 490).

Em consonância com o texto legal, a perspectiva de Silva encaminha para o entendimento da ERER como uma política curricular que está comprometida com um novo projeto educativo pensado não mais para a sustentação do racismo estrutural brasileiro, mas para a diversidade e para uma nova composição das relações étnico-raciais. Logo, é de responsabilidade de professoras e professores o trabalho qualificado com a ERER em sala de aula; as Diretrizes apontam que

\footnotetext{
2. As concepções de raça e, consequentemente, de minoria com a qual operamos aqui é eminentemente social. Isso significa que o olhar analítico que lançamos para os processos da sociedade observa as condições objetivas de produção das desigualdades sem se que exclua a racialização dos sujeitos. O racismo, nesse contexto, caracteriza-se pela predisposição de lugares subalternos para a população negra em todas as posições sociais. Esse ponto de vista é fundamentado em uma vasta produção de intelectuais negros e negras que observam os processos de racialização como mecanismo fundamental de uma sociedade estruturada pelo racismo. Entre eles estão Sueli Carneiro (2005), Abdias Nascimento (2016), Silvio Almeida (2018), Frantz Fanon (2008), entre outros e outras. Dessa forma, o que se denomina como minoria social vai além do simples aspecto quantitativo, porque olha para a garantia de acesso aos direitos sociais e para sociabilidade forjada pelo modelo de sociedade capitalista em que vivemos. Sabe-se, por diversos estudos, que a população brasileira é composta majoritariamente por negros (que compreende pretos e pardos). Contudo, isso não se traduz em equidade na ocupação dos espaços sociais entre negros e brancos em nenhuma esfera. A esse respeito, a reflexão de Abdias Nascimento (2016) nos é cara: "Se os negros vivem nas favelas porque não possuem meios para alugar ou comprar residência nas áreas habitáveis, por sua vez a falta de dinheiro resulta da discriminação no emprego. Se a falta de emprego é por causa de carência de preparo técnico e de instrução adequada, a falta desta aptidão se deve à ausência de recurso financeiro. Nesta teia, o afro-brasileiro se vê tolhido de todos os lados, prisioneiro de um círculo vicioso de discriminação - no emprego, na escola - e trancadas as oportunidades que lhe permitiriam melhorar suas condições de vida, sua moradia, inclusive. Alegações de que esta estratificação é "não racial" ou "puramente social e econômica" são chavões que se repetem e racionalizações basicamente racistas: pois o fator racial determina a posição social e econômica na sociedade brasileira” (NASCIMENTO, 2016, p. 101).
} 
[...] para obter êxito, a escola e seus professores não podem improvisar. Têm que desfazer mentalidade racista e discriminadora secular, superando o etnocentrismo europeu, reestruturando relações étnico-raciais e sociais, desalienando processos pedagógicos. Isso não pode ficar reduzido a palavras e raciocínios desvinculados da experiência de ser inferiorizados vivida pelos negros, tampouco das baixas classificações que lhe são atribuídas nas escalas das desigualdades sociais, econômicas, educativas e políticas. (BRASIL, 2004, p. 15, grifos nossos).

Pensando nisso, discutiremos, na sequência, a seleção de textos para uma aula de LPL que se quer antirracista e exploraremos a leitura literária como uma experiência a ser compartilhada coletivamente, o que dialoga diretamente com uma proposta de ensino que não seja sustentada pelo racismo.

\section{Da seleção de textos à leitura literária como experiência}

Conceição e Neves (2020), em um importante estudo, tematizam a educação antirracista e interseccional pela proposição de materiais didáticos. Nesse viés, as autoras defendem que, para que a educação étnico-racial e de gênero seja concretizada, as legislações são essenciais, no entanto

[...] elas por si só não garantem que a escola se comprometa com um ensino que valorize a diversidade de saberes e conhecimentos, distanciando-se de uma perspectiva eurocêntrica. É pungente que as instituições escolares repensem seus currículos e processos avaliativos e que invistam em formação de professores, ações pedagógicas e, principalmente, nas relações interpessoais entre as pessoas que constituem a escola. Além disso, é mister que se preste mais atenção nos materiais didático-pedagógicos utilizados [...]. (CONCEIÇÃO; NEVES, 2020, p. 164).

Ao abordarem a importância da práxis, Conceição e Neves (2020) trazem à tona o problema do currículo de LPL, sobretudo quando este está construído, muitas vezes, para a manutenção de um modus operandi da sala de aula hegemônica. Desse modo,

Nas práticas pedagógicas, por inúmeras vezes, não é considerada a diversidade de classe, raça, idade, cultura, crenças na qual currículo e conteúdos deveriam ser pautados, os quais não variam e são abordados independentemente das pessoas que ali estão, priorizando-se uma lista de conteúdos que "necessitam" ser abordados e se desconsiderando uma educação linguística que leva em conta o perfil de estudantes, suas identidades e suas vivências como algo valioso para um trabalho de língua, com a língua e na língua. (CONCEIÇÃO; NEVES, 2020, p. 165-166, grifos nossos).

Neste ponto, a legislação encontra um papel importante de política pública, pois respalda o professor e a instituição que questionar o currículo. Desta maneira, para que a prática seja efetivada, acreditamos que a proposta de Simões et al. (2012) inspira projetos de ensino que contemplem as distintas vivências e identidades encontradas em uma comunidade escolar. Simões et al. (2012) consideram que a seleção de textos é o pilar fundamental em LPL. Nesse sentido, um planejamento eficiente e que, segundo nossa visão, carregue consigo uma concepção antirracista passa inegavelmente pela seleção de textos, bem como pelo assunto e pelo tema que se quer abordar. Por consequência, é o corpus, a saber, os textos escolhidos para o projeto de ensino, que dita as habilidades e os conteúdos a serem desenvolvidos no processo de ensino-aprendizagem; isso porque, durante a curadoria de textos, deparamo-nos com a eleição de um gênero estruturante - e, em alguns casos, também a escolha de gênero secundários - que apresenta um tema e algumas perguntas a serem resolvidas, o que nos conduz novamente à seleção de textos como peça chave para um projeto de ensino. Então, 
[...] o professor começa por montar um acervo de textos a serem lidos ao longo das aulas para três funções: acima de tudo, para proporcionar a aprendizagem das dimensões textuais do gênero estruturante e para a busca de conteúdos sobre os temas de que tratarão os alunos em suas produções escritas. É nesse contexto vivo e impregnado de sentidos que vamos encaixar as aprendizagens de língua e de literatura oportunizadas pelos textos. (SIMÕES et al., 2012, p. 101).

Em um projeto de ensino, para além da leitura de textos do gênero estruturante, há espaço para a seleção de "textos para aprender", isto é, "textos ligados à temática, para aprender sobre ela e para qualificar a produção de textos” (SIMÕES et al., 2012, p. 101). Tal coletânea é fundamental para a alimentação temática e é neste último eixo que nos demoraremos um pouco mais. Nessa perspectiva, assumimos que o texto literário não precisa estar ligado ao produto final de um projeto de ensino. $\mathrm{O}$ que dita o estatuto dos textos literários no processo de ensino-aprendizagem depende do objetivo de ensino e dialoga com a alimentação temática de um projeto; porém, acreditamos que há um "lugar" inquestionável para um texto literário abordado em sala de aula: o da experiência.

Eleger textos, destarte, implica sujeitos reais e situados que serão leitores e experienciadores dessas obras a partir de suas vivências. No entanto, isso não significa que a curadoria de textos se restrinja ao conhecimento de mundo do aluno, tampouco que deva alicerçar-se em um cânone ou em produções estranhas aos educandos. O movimento que aqui propomos é simbiótico: interessa-nos o que a leitura de dado texto significa para o aluno e como se relaciona com a sua vivência, não como espelho ou problematização, mas como mediação de uma experiência possível.

Nesse domínio, entendemos a literatura, que é o objeto da educação literária, como um direito, na mesma perspectiva que o sociólogo Antonio Candido (2011) a defende como parte do conjunto de bens incompressíveis do qual o ser humano não pode ser destituído:

São incompressíveis certamente a alimentação, a moradia, o vestuário, a instrução, a saúde, a liberdade individual, o amparo da justiça pública, a resistência à opressão etc.; e também o direito à crença, à opinião, ao lazer e, por que não, à arte e à literatura. [...] elas [a arte e a literatura] só poderão ser consideradas bens incompressíveis segundo uma organização justa da sociedade se corresponderem a necessidades profundas do ser humano, a necessidades que não podem deixar de ser satisfeitas sob pena de desorganização pessoal, ou pelo menos de frustração mutiladora. (CANDIDO, 2011, p. 176).

Na prática, isso significa conceber a literatura como uma manifestação fundamentalmente humana e como produtora de sentido nas sociedades. Também implica em dotar à educação linguística e literária de um potencial político:

A especificidade da literatura está na vivência de experiências humanas através da mediação de uma forma estética particular. E essas vivências são fundamentais não apenas para a formação escolar ou acadêmica do aluno, mas também para o incremento de sua percepção de si mesmo e do mundo, sendo, ademais, um sempiterno estímulo à intervenção na realidade injusta, que, quase todos concordamos, precisa ser transformada e humanizada. (PILATI, 2017, p. 12).

A leitura literária aparece na sala de aula como uma experiência que possibilita aos indivíduos constituírem seus lugares como sujeitos em sociedade. Para que essa possibilidade seja efetivada, parece-nos latente a tarefa do professor de construir tarefas de leituras que ensejem um espaço de diálogo com os textos literários. A prática da ERER, da mesma forma, pressupõe intercâmbio de experiências porque, antes de tudo, trata da afirmação das identidades compostas a partir de distintas sociabilidades. 


\section{Da teoria à prática}

Almejamos, nesta seção, a partir do arcabouço desenvolvido nas seções anteriores, apresentar uma proposta de ensino que contempla as tarefas de pré-leitura e as tarefas de sondagem em um projeto de ensino hipotético. Igualmente, procuramos efetuar o movimento de teoria-prática-teoria ao procedermos a análise de cada tarefa.

\section{O projeto}

À guisa de contextualização, abaixo, apresentamos um exemplo de projeto para propormos, doravante, a seleção de textos e as atividades de leitura nelas inspiradas.

\section{Quadro 1 - Apresentação do projeto}

\begin{tabular}{|c|c|}
\hline Etapa de ensino & $9^{\circ}$ ano do Ensino Fundamental \\
\hline $\begin{array}{l}\text { Eixo temático } \\
\text { interdisciplinar }\end{array}$ & As relações de afeto na sociedade \\
\hline $\begin{array}{l}\text { Problematização } \\
\text { disciplinar }\end{array}$ & $\begin{array}{l}\text { Como o amor assume sentidos distintos na poesia produzida por diferentes gera- } \\
\text { ções? Como tais sentidos dialogam com a concepção de cada estudante? Como tal } \\
\text { definição dá conta dos segmentos sociais? }\end{array}$ \\
\hline $\begin{array}{l}\text { Gênero (oral e/ou escrito) } \\
\text { estruturante }\end{array}$ & Verbete \\
\hline $\begin{array}{l}\text { Gêneros secundários } \\
\text { (leituras para alimentação } \\
\text { temática) }\end{array}$ & Poesia e canção \\
\hline $\begin{array}{l}\text { Objetivos disciplinares do } \\
\text { projeto }\end{array}$ & $\begin{array}{l}\text { Proporcionar a experiência de leitura de diferentes gêneros do discurso que } \\
\text { abordem a temática do afeto, observando, no processo de leitura, a especificidade } \\
\text { dos textos literários envolvidos. }\end{array}$ \\
\hline $\begin{array}{l}\text { Textos para leitura e } \\
\text { planejamento de tarefas } \\
\text { em aulas }\end{array}$ & $\begin{array}{l}\text { "Quem sabe isso quer dizer amor", interpretada por Milton Nascimento } \\
\text { "Vivendo de amor", de bell hooks } \\
\text { Seleção de poemas feita pelos professores (Anexo) }\end{array}$ \\
\hline $\begin{array}{l}\text { Textos longos para leitura } \\
\text { no mês, trimestre ou } \\
\text { semestre }\end{array}$ & $\begin{array}{l}\text { Insubmissas lágrimas de mulher, de Conceição Evaristo ou O Beijo na parede, de } \\
\text { Jeferson Tenório. }\end{array}$ \\
\hline Tarefas preparatórias & $\begin{array}{l}\text { a) leitura de imagens e canções (alimentação temática); } \\
\text { b) produção diagnóstica de uma pequena definição sobre o que seja amor para } \\
\text { cada educando. }\end{array}$ \\
\hline Competências nucleares & Leitura e escrita \\
\hline Conteúdos disciplinares & $\begin{array}{l}\text { Previamente: paráfrase; os demais conteúdos são mapeados a partir da produção } \\
\text { diagnóstica dos educandos. }\end{array}$ \\
\hline
\end{tabular}

Fonte: Elaborado pela autora e pelo autor.

O quadro acima sintetiza uma proposta de ensino que interpela os sentidos que o amor assume na poesia produzida por diferentes gerações. Tal projeto inspira-se sobretudo no ensaio intitulado "Vivendo de amor”, da filósofa antirracista estadunidense bell hooks (HOOKS, 2010 [1994]). Hooks defende que as mulheres negras foram, devido ao contexto sócio-histórico de escravização nos Estados Unidos, privadas da prática do amor como uma forma de sobrevivência. Logo, a defesa de que o afeto seja um direito da 
população não branca torna-se essencial para que se possa alterar estruturas sociais existentes e promover formas de vidas mais saudáveis diante do genocídio negro e indígena. Neste contexto, deslocamos as proposições da filósofa estadunidense para o contexto de ensino em que os sujeitos inseridos nos espaços escolares têm diferentes pertenças étnico-raciais e diferentes vivências.

Por esse prisma, acreditamos que a tese de hooks propõe uma chave dialética para pensar, além da sobrevivência e dos direitos da população negra, o papel nocivo que a cultura da branquitude provoca tanto para a população negra quanto para si mesma. A literatura e o ensino de língua inserem-se e dialogam com este ponto de vista pelas suas capacidades de afetarem os sujeitos pela experiência e por tal vivência configurar-se como uma potência humanizadora (CANDIDO, 2011). Por fim, a curadoria de textos feitas para o projeto passa essencialmente por uma dimensão política do que se entende como o objeto a ser ensinado em LPL quando se trata de Literatura e questões linguísticas. Sem demora, passemos às tarefas.

\section{Tarefas}

Figura 1 - Momento 1: Tarefa 1

\section{Momento 1: Audição}

>> “Quem sabe isso quer dizer amor” é uma canção lançada em 2005, de Milton Nascimento. Ouça a canção enquanto observa as imagens que estão sendo passadas e pense: o que elas representam? Elas têm algo em comum? Como se distanciam?
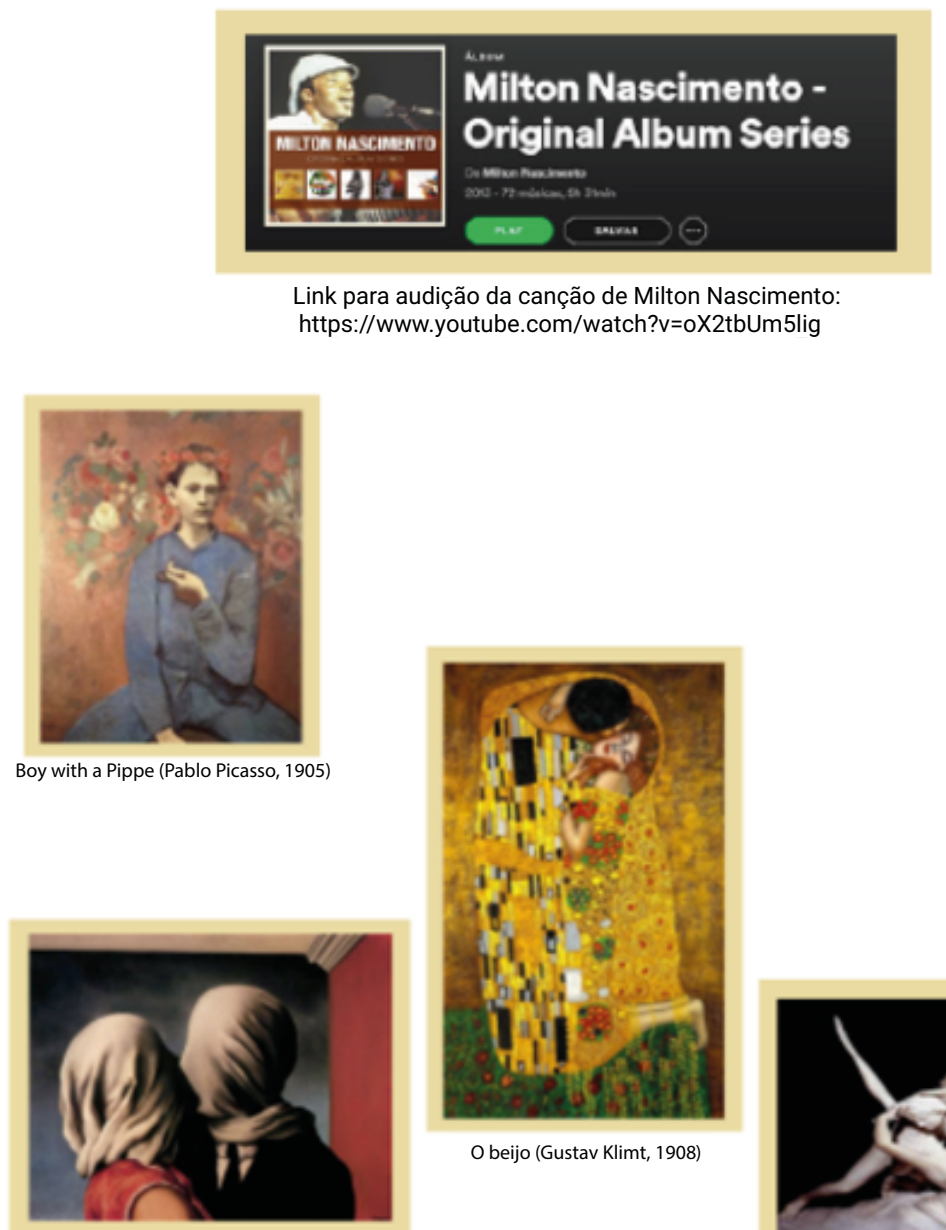

O beijo (Gustav Klimt, 1908)

Os Amantes (Magritte. 1928)

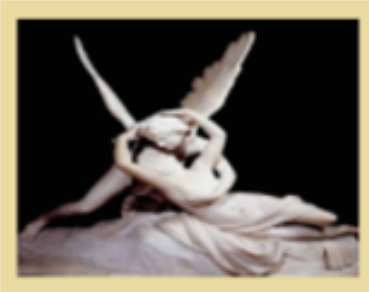

Psique reanimada pelo Beijo do Amor (Antonio Canova) 
As tarefas apresentadas abrem o conjunto das tarefas de pré-leitura. Logo, ao mobilizarmos o texto literário do gênero canção e as obras de arte, queremos despertar e trazer à cena da sala de aula os conhecimentos dos educandos acerca da temática que se apresenta nas imagens: o amor. Destarte, ainda não abordamos o gênero discursivo a ser desenvolvido ao longo do projeto, pois, neste momento, importa-nos a sensibilização com a temática, a fruição e a evocação de sentidos distintos com as obras envolvidas.

Além disso, a mediação da audição e da leitura das obras de arte pode ser feita justamente pela via imagética. Milton Nascimento, em sua canção, dispõe de distintas imagens para construir um cenário para o amor; então, vemos que o compositor adere a uma forma estética específica: a forma com que Nascimento diz o que diz sobre o amor é determinante para o entendimento da canção. Tal “forma de dizer" parece-nos interessante de ser abordada em aula e uma forma de mediação da leitura e da interpretação das obras de arte. Acerca das pinturas, podemos remarcar com os educandos as semelhanças e as distinções entre elas, seja nos termos de representação, seja nos termos de composição (cores, elementos etc).

Durante a mediação de leitura e a socialização das impressões da audição, o professor pode suscitar outras questões e problematizar as representações do amor, por meio de questões como: "que outras obras e imagens vocês inseririam no acervo para representar o amor de vocês?”. Tal movimento convida os educandos à tomada do turno de fala e a trazerem suas vivências para o espaço da aula de LPL.

\section{Figura 3 - Momento 2: Tarefas 2 e 3}

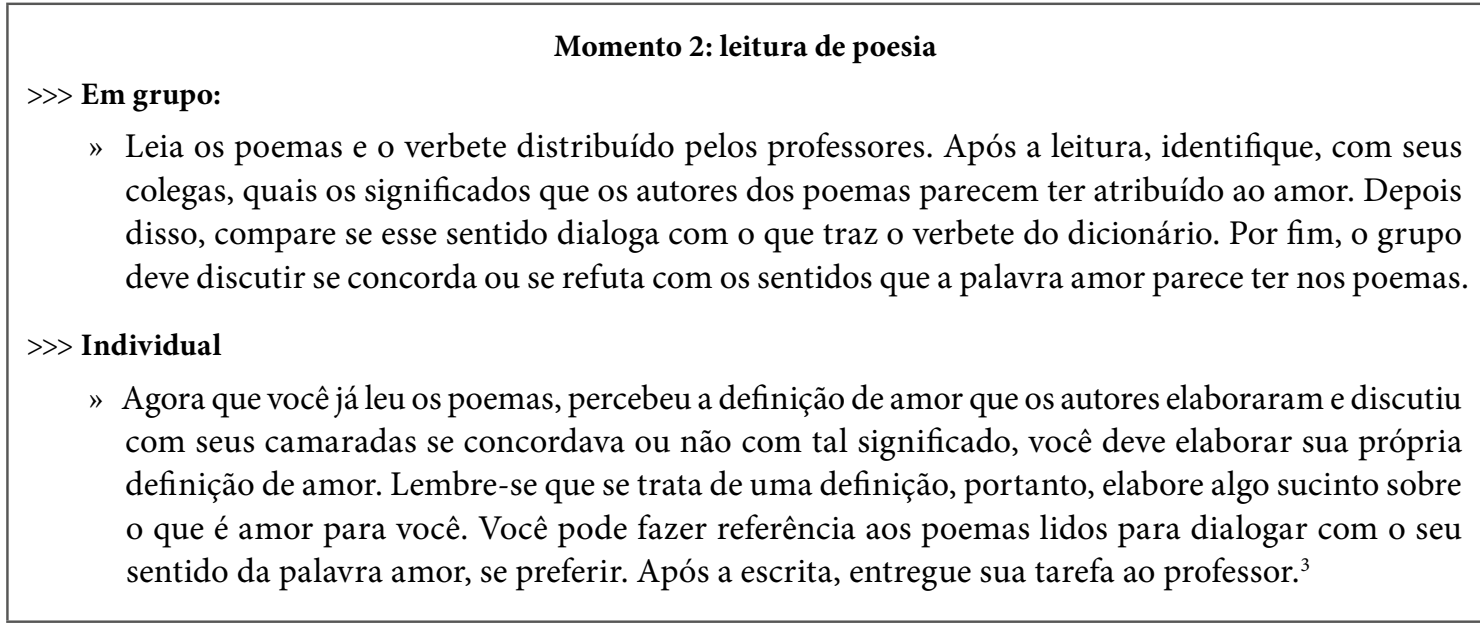

Fonte: Elaborado pela autora e pelo autor.

O conjunto de tarefas acima insere textos literários do gênero poesia. Como abordamos na seção anterior, entendemos que a literatura, em projetos de ensino, não implica necessariamente uma produção a partir dela. Importa-nos, antes de tudo, a experiência, a fruição com o texto literário e o que Alexandre Pilati (2017) nos diz sobre a mediação entre a vivência humana e a forma estética; tal mediação é feita dialeticamente pela criatividade e pela experiência de um leitor ao envolver o texto literário e o mundo a serem interpretados esteticamente. Evidentemente, esse movimento inicial não se esgota: os poemas selecionados para a pré-leitura podem ser retomados durante o desenvolvimento do projeto para serem

\footnotetext{
3. Fazemos uma breve ressalva a propósito da avaliação da produção realizada pelos educandos a ser entregue para o professor. Por se tratar do início de um projeto de ensino, tal tarefa tem a função de servir como "bússola", isto é, uma produção diagnóstica, para o docente perceber os aspectos linguísticos relevantes a serem aprofundados a partir da necessidade dos educandos. Posteriormente, ao retornar a tarefa ao alunado, o professor tem a função de mediar a discussão com a comunidade de leitores formada em sala de aula. Nesse viés, alinhamo-nos a Cosson (2018), que entende a avaliação como compartilhada, aberta e atenta aos leitores-alunos. Finalmente, ainda nas trilhas das proposições de Cosson (2018), adotamos a ideia de que a leitura literária não é algo se deva avaliar em termos de "conteúdo", em realidade, cabe a avaliação o espaço de experiência e negociação de leituras/ interpretações. A avaliação em literatura, em decorrência do recorte temático do presente trabalho, será desenvolvida em estudo posterior a este que ora apresentamos.
} 
estudados e analisados. Em suma, ao tomarmos essa posição, investimos na "latência transformadora" da poesia em sala de aula (PILATI, 2017).

Além disso, ao lançarmos mão de uma diversidade de autoras e autores pertencentes às épocas, às classes sociais e às raças distintas, situamo-nos no entendimento do que Cosson (2018) propõe como experiência literária: não se trata somente de uma "informação" e um "reconhecimento" da vida de um outro, mas também a possibilidade de vivenciar a experiência de um outro, que é estranha ou semelhante às experiências dos educandos envolvidos. Isso permite que voltemos ao nosso entendimento inicial acerca da ERER: ela é concebida como uma alternativa para que não brancos e brancos repactuem as relações sociais; nessa perspectiva, a seleção de textos deve contemplar tal concepção. Ao justapor na seleção de poemas nomes como o de Conceição Evaristo e Gessica com Gê aos de Carlos Drummond de Andrade, Mário Quintana e Rupi Kaur, tensionamos as noções canônicas de poesia e abrimos espaço para novas vozes articuladas às experiências. A poesia assume ainda outra dimensão política: a de ser contra hegemônica na medida em que traz à cena a urgência de "coisas não imediatas” (PILATI, 2017).

Enfim, a produção sugerida ao final da leitura dos textos literários é uma “bússola” para o professor acerca das questões linguísticas a serem centralizadas ao longo do projeto de ensino e acerca do que os alunos já conhecem acerca do gênero estruturante do projeto. No entanto, além de ser norteadora para o projeto, a produção diagnóstica convoca novamente a dialética entre a experiência dos educandos e o texto literário; isso porque permite que os educandos dialoguem com a voz dos autores e dos camaradas de classe para construírem o seu próprio entendimento do que seja o amor, ou seja, somos reconduzidos à ideia de que a forma estética interpreta o mundo e realiza a mediação de uma dada experiência.

\section{Considerações finais}

Este trabalho problematizou a seleção de textos das aulas de Língua Portuguesa e Literatura (LPL) do Ensino Fundamental - baseando-se nos pressupostos da Educação das Relações Étnico-Raciais (ERER) - e tematizou a leitura literária pelo viés da experiência dos sujeitos históricos em sociedade. Para tanto, percorremos a legislação vigente e as discussões epistemológicas que a sucederam, as elucubrações teóricas acerca da seleção de textos e da leitura literária em LPL e, finalmente, embasados em tais pressupostos, propomos um possível projeto de ensino com suas tarefas de pré-leitura para exemplificarmos uma seleção de textos que levasse em conta os pressupostos da ERER e uma educação linguística e literária antirracista. Nesse sentido, entendemos que a seleção de textos e a leitura concebida como uma experiência é uma chave interpretativa possível para a concretização de uma educação linguística e literária que não esteja pautada pelo silenciamento dos conflitos raciais que surgem em sala de aula como consequência daqueles que já existem na sociedade.

Em suma, este estudo espera contribuir com o ensino de LPL e com a práxis da ERER, como também com a discussão sobre leitura literária pela perspectiva da experiência. Assim, não buscamos encerrar a discussão, porém, juntarmo-nos a mais uma provocação sobre um outro ensino de Língua Portuguesa e de Literatura possível. Por isso, para encerrar nossa reflexão, tomamos o que escreve Ailton Krenak na obra Ideias para adiar o fim do mundo (2019):

Nosso tempo é especialista em criar ausências: do sentido de viver em sociedade, do próprio sentido da experiência da vida. Isso gera uma intolerância muito grande com relação a quem ainda é capaz de experimentar o prazer de estar vivo, de dançar, de cantar. E está cheio de pequenas constelações de gente espalhada pelo mundo que dança, canta, faz chover. $\mathrm{O}$ tipo de humanidade zumbi que estamos sendo convocados a integrar não tolera tanto prazer, tanta fruição de vida. Então, pregam o fim do mundo como uma possibilidade de fazer a gente desistir dos nossos próprios sonhos. E a minha provocação sobre adiar o fim do mundo é exatamente sempre poder contar mais uma história. Se pudermos fazer isso, estaremos adiando o fim. (KRENAK, 2019, p. 13, grifos nossos). 
Em nosso contexto, somamos e deslocamos a passagem: se pudermos contar mais uma história e de outra perspectiva de sala de aula, estaremos também adiando o fim do mundo e possibilitando que novas experiências sejam vividas e contadas.

\section{Referências}

ALMEIDA, Silvio. O que é Racismo Estrutural? Belo Horizonte: Letramentos, 2018.

BAGNO, Marcos; RANGEL, Egon de Oliveira. Tarefas da educação linguística no Brasil. Revista Brasileira de Linguística Aplicada, v. 5, n. 1, 2005. Disponível em: https://www.scielo.br/scielo.php?script=sci_arttext\&pid= S1984-63982005000100004. Acesso em: 3 out. 2020.

BRASIL. Lei no 9.394, de 20 de dezembro de 1996. Estabelece as diretrizes e bases da educação nacional. Diário Oficial da União: seção 1, Brasília, DF, p. 27.833, 23 dez. 1996. Disponível em: http://www.planalto.gov.br/ccivil_03/leis/19394. htm. Acesso em: 15 ago. 2020.

BRASIL. Lei $\mathrm{n}^{\circ}$ 10.639, de 9 de janeiro de 2003. Altera a Lei $\mathrm{n}^{\circ}$ 9.394, de 20 de dezembro de 1996, que estabelece as diretrizes e bases da educação nacional, para incluir no currículo oficial da Rede de Ensino a obrigatoriedade da temática "História e Cultura Afro-Brasileira", e dá outras providências. Diário Oficial da União: seção 1, Brasília, DF, p. 1, 10 jan. 2003. Disponível em: http://www.planalto.gov.br/ccivil_03/leis/2003/110.639.htm. Acesso em: 15 ago. 2020.

BRASIL. Lei $\mathrm{n}^{\circ}$ 11.645, de 10 março de 2008. Altera a Lei $\mathrm{n}^{\circ}$ 9.394, de 20 de dezembro de 1996, modificada pela Lei $\mathrm{n}^{\circ}$ 10.639, de 9 de janeiro de 2003, que estabelece as diretrizes e bases da educação nacional, para incluir no currículo oficial da rede de ensino a obrigatoriedade da temática "História e Cultura Afro-Brasileira e Indígena". Diário Oficial da União: seção 1, Brasília, DF, p. 1, 11 mar. 2008. Disponível em: http://www.planalto.gov.br/ccivil_03/_Ato20072010/2008/Lei/L11645.htm. Acesso em: 10 ago. 2020.

BRASIL. Ministério da Educação. Parecer CNE/CP n 003/2004. Diretrizes Curriculares Nacionais para a Educação das Relações Étnico-Raciais e para o Ensino de História e Cultura Afro-Brasileira e Africana. Diário Oficial da União: seção 1, Brasília, DF, p. 19, 19 maio 2004. Disponível em: http://portal.mec.gov.br/dmdocuments/cnecp_003.pdf. Acesso em: 28 jul. 2020.

CANDIDO, Antonio. O direito à literatura. In: CANDIDO, Antonio. Vários escritos. 5. ed. Rio de Janeiro: Ouro sobre Azul, 2011. p. 171-193.

CARNEIRO, Sueli. A construção do Outro como Não-Ser como fundamento do ser. 2005. 339 f. Tese (Doutorado em Educação) - Programa de Pós-Graduação em Educação, Universidade de São Paulo, São Paulo, 2005.

CONCEIÇÃO, Janaína Vianna da; NEVES, Caroline Scheuer. Interseccionalidade e educação antirracista no ensino de português e literatura: considerações para uma proposta de material didático. Calidoscópio, São Leopoldo, v. 18, n. 1, p. 162-183, 2020. Disponível em: http://revistas.unisinos.br/index.php/calidoscopio/article/view/cld.2020.181.09. Acesso em: 15 ago. 2020.

COSSON, Rildo. Letramento literário: teoria e prática. São Paulo: Contexto, 2018.

FANON, Frantz. Pele negra, máscaras brancas. Tradução de Renato da Silveira. Salvador: EDUFBA, 2008.

HOOKS, bell. Vivendo de amor. Portal Gelédes, São Paulo, 9 mar. 2010. Disponível em: https://www.geledes.org.br/ vivendo-de-amor/. Acesso em: 27 abr. 2021.

KRENAK, Ailton. Ideias para adiar o fim do mundo. São Paulo: Schwarcz, 2019.

NASCIMENTO, Abdias. O genocídio do negro brasileiro. São Paulo: Perspectivas, 2016.

PILATI, Alexandre. Poesia na sala de aula: subsídios para pensar o lugar e a função da literatura em ambientes de ensino. Campinas: Pontes Editores, 2017.

SANTOS, Elisabete Figueroa dos; PINTO, Eliane Aparecida Toledo; CHIRINÉA, Andréia Melanda. A Lei 10.639 e o Epistemicídio: relações e embates. Educação \& Realidade, Porto Alegre, v. 43, n. 3, p. 949-967, 2018. Disponível em: https://www.scielo.br/scielo.php?script=sci_arttext\&pid=S2175-62362018000300949\&lng=pt\&nrm=iso\&tlng=pt. Acesso em: 23 jun. 2020.

SILVA, Petronilha Beatriz Gonçalves e. Aprender, ensinar e relações étnico-raciais no Brasil. Educação, Porto Alegre, v. 30, n. 3, p. 489-506, 2007. Disponível em: http://revistaseletronicas.pucrs.br/ojs/index.php/faced/article/view/2745. Acesso em: 24 jun. 2020. 
SILVA, Petronilha Beatriz Gonçalves e. Educação das Relações Étnico-Raciais nas instituições escolares. Educar em Revista, Curitiba, v. 34, n. 69, p. 123-150, 2018. Disponível em: https://www.scielo.br/scielo.php?script=sci_abstract\&pid= S0104-40602018000300123\&lng=pt\&nrm=iso. Acesso em: 24 jun. 2020.

SILVA, Petronilha Beatriz Gonçalves e. Como educar-se/educar num mundo de crescentes desigualdades? Crítica Educativa, Sorocaba, v. 5, n. 1, p. 10-20, 2019. Disponível em: http://www.criticaeducativa.ufscar.br/index.php/ criticaeducativa/article/view/438. Acesso em: 25 jun. 2020.

SIMÕES, Luciene et al. Leitura e Autoria: planejamento em língua portuguesa e literatura. Erechim: Edelbra, 2012.

\section{Outras obras utilizadas durante a execução do projeto}

AMOR. In: DICIO, Dicionário Online de Português. Porto: 7Graus, 2020. Disponível em: http://michaelis.uol.com.br/ busca? $\mathrm{r}=0 \& \mathrm{f}=0 \& \mathrm{t}=0$ \&palavra=amor. Acesso em: 15 agosto 2020 .

ANDRADE, Carlos Drummond de. Nova reunião: 19 livros de poesia. 2. ed. Rio de Janeiro: José Olympio, 1985.

CANOVA. Antonio. Psiquê reanimada pelo beijo do Amor. 1793. 1 escultura, mármore. Disponível em: https:/guiadolouvre. com/psique-reanimada-pelo-beijo-do-amor/. Acesso em: 10 de agosto de 2020.

EVARISTO, Conceição. De mãe. In: RIBEIRO, Esmeralda; BARBOSA, Márcio (org.). Cadernos Negros: poemas afro-brasileiros. São Paulo: Quilombhoje, 2002. 25 v.

EVARISTO, Conceição. Insubmissas lágrimas de mulheres. Rio de Janeiro: Malê Edições, 2016.

FELIX, Natasha. Poema sem título. Disponível em: https://medium.com/mulheres-que-escrevem/quatro-poemas-denatasha-felix-elf3468a4a6. Acesso em: 15 ago. 2020.

GÉSSICA COM GÊ. Poema - Para o primeiro amor. Géssica com Gê, 5 fevereiro de 2009. Disponível em: https://gessicacomge. com.br/2009/02/05/poema-para-o-primeiro-amor/. Acesso em: 15 ago. 2020.

KAUR, Rupi. Outros jeitos de usar a boca. São Paulo: Planeta, 2017.

KLIMT, Gustav. Der Kuss. 1907-1908. Óleo sobre tela. 1,8 x 1,8 m Disponível em: https://www.belvedere.at/en/ kiss-gustav-klimt. Acesso em: 10 ago. 2020.

LEÃO, Ryane. Para que te amem. Disponível em: https://www.buzzfeed.com/br/ramosaline/poemas-que-vao-tefazer-pensar-sobre-o-amor. Acesso em: 15 ago. 2020.

MAGRITTE, René. The Lovers. 1928. Pintura, óleo sobre tela. 54 x 73 cm. Disponível em: https://www.moma.org/ collection/works/79933. Acesso em: 10 ago. 2020.

NETO, João Cabral de Melo. Os Três Mal-Amados. Disponível em: http://www.releituras.com/joaocabral_malamados. asp. Acesso em: 15 ago. 2020.

PICASSO, Pablo. Garçon à la pipe. 1905. Pintura, óleo sobre tela. $1 \mathrm{~m} \times 81,3 \mathrm{~cm}$. Disponível em: https://www.pablopicasso.org/ boy-with-pipe.jsp. Acesso em: 10 ago. 2020.

QUEM sabe isso quer dizer amor. Compositores: Márcio Borges, Lô Borges. Intérprete: Milton Nascimento. Rio de Janeiro: Warner Music Brasil, 2013. 1 CD, faixa 5. Disponível em: https://open.spotify.com/album/1sX0IhEk3YSlQzlfvdlren?si= bon9-tZeSRekb4V1xGbI9w. Acesso em: 10 ago. 2020.

QUINTANA, Mário. Bilhete. Disponível em: https://www.culturagenial.com/poema-bilhete-mario-quintana/. Acesso em: 10 ago. 2020.

TENÓRIO, Jeferson. O beijo na parede. Porto Alegre: Sulina, 2013. 


\section{Apêndice}

\section{SELETA DE POEMAS}

O amor bate na aorta, de Carlos Drummond de Andrade

\section{Cantiga de amor sem eira}

nem beira,

vira o mundo de cabeça

para babo,

suspende a saia das mulheres,

tira os óculos dos homens.

o amor, seja como for,

é o amor.

Meu bem, não chores,

hoje tem filme do Carlito.

O amor bate na porta

o amor bate na aorta,

fui abrir e me constipei.

Cardiaco e melancólico,

o amor ronca na horta

entre pés de laranjeira

entre uvas meio verdes

e desejos já maduros.

Entre uvas meioverdes,

meu amor, năo te atormentes.

certos acidos adoçam

a boca murcha dos velhos

e quando os dentes não mordem

e quando os braços nāo prendem

- amor faz uma cócega

o amor desenha uma curva

propōe uma geometria.

Amor é bicho instruido.

Olha: o amor pulou o muro

o amor subiu na árvore

em tempo de se estrepar

Pronto, o amor se estrepou.

Daqui estou vendo o sangue

que escorre do corpo andrógino.

Essa ferida, meu bem,

as vezes não sara nunca.

às vezes sara amanhã.

Daqui estou vendo o amor

irritado, desapontado,

mas também vejo outras coisas:

vejo corpos, vejo almas

vejo beijos que se beijam

ouco máos que se conversam

e que viajam sem mapa.

Vejo muitas outras coisas

que năo ouso compreender.

\section{Os três mal-amados, de João Cabral de Melo Neto}

O amor comeu meu nome, minha identidade, meu retrato. $\mathrm{O}$ amor comeu minha certid 3 o de idade,

minhá genealogia, meu endereço. $\mathrm{O}$ amor

comeu meus cartōes de visita. O amor veio e comeu todos

os papéis onde eu escrevera meu nome.
O amor comeu minhas roupas, meus lenços, minhas camisas. $\mathrm{O}$ amor comeu metros e metros de gravatas. $\mathrm{O}$ amor comeu a medida de meus ternos. o número de meus sapatos, o tamanho de meus chapéus. O amor comeu minha altura, meu peso, a cor de meus olhos e de meus cabelos.

0 amor comeu meus remédios, minhas receitas médicas, minhas dietas. Comeu minhas aspirinas, minhas ondas-curtas, meus raios- $\mathrm{X}$. Comeu meus testes mentais, meus exames de urina.

O amor comeu na estante todos os meus livros de poesia. Comeu em meus livros de prosa as citaçōes em verso. Comeu no dicionário as palavras que poderiam se juntar em versos.

Faminto, o amor devorou os utensilios de meu uso: pente, navalha, escovas, tesouras de unhas. canivete. Faminto ainda, o amor devorou o uso de meus utensílios: meus banhos frios, a ópera cantada no banheiro, o aquecedor de água de fogo morto mas que parecia uma usina.

O amor comeu as frutas postas sobre a mesa. Bebeu a água dos copos e das quartinhas. Comeu o pão de propósito escondido. Bebeu as lágrimas dos olhos que, ninguém o sabia, estavam cheios de água.

O amor voltou para comer os papéis onde irrefletidamente eu tornara a escrever meu nome. O amor roeu minha infância, de dedos sujos de tinta,

cabelo caindo nos olhos, botinas nunca engraxadas. o amor roeu o menino esquivo, sempre nos cantos. e que riscava os livros, mordia o lápis, andava na rua chutando pedras. Roeu as conversas, junto à bomba de gasolina do largo, com os primos que tudo sabiam

sobre passarinhos, sobre uma mulher, sobre marcas de automóvel.

O amor comeu meu Estado e minha cidade. Drenou a

água morta dos mangues, aboliu a maré. Comeu os mangues crespos e de folhas duras, comeu o verde ácido das plantas de cana cobrindo os morros

regulares, cortados pelas barreiras vermelhas, pelo trenzinho preto, pelas chaminés. Comeu o cheiro de cana cortada e o cheiro de maresia. Comeu até essas

coisas de que eu desesperava por não saber falar delas em verso.

O amor comeu até os dias ainda não anunciados nas folhinhas. Comeu os minutos de adiantamento de meu relógio, os anos que as linhas de minha măo asseguravam. Comeu o futuro grande atleta, o futuro

grande poeta. Comeu as futuras viagens em volta da terra, as futuras estantes em volta da sala.

o amor comeu minha paz e minha guerra. Meu dia e

minha noite. Meu inverno e meu verão. Comeu meu silêncio, minha dor de cabeça, meu medo da morte. 
As sem-razōes do amor, de Carlos Drummond de Andrade

Eu te amo porque te amo.

Näo precisas ser amante,

e nem sempre sabes sè-lo.

Eu te amo porque te amo.

Amor é estado de graça

e com amor nāo se paga.

Amor é dado de graça,

é semeado no vento.

na cachoeira, no eclipse.

Amor foge a dicionários

e a regulamentos vários.

Eu te amo porque năo amo

bastante ou de mais a mim.

Porque amor nāo se troca,

não se conjuga nem se ama.

porque amor é amor a nada.

feliz e forte em si mesmo.

Amor é primo da morte,

e da morte vencedor,

por mais que o matem (e matam)

a cada instante de amor.

\section{Bilhete, de Mário Quintana}

Se tu me amas, ama-me baixinho

Não o grites de cima dos telhados

Deixa em paz os passarinhos

Deixa em paz a mim!

Se me queres.

enfim.

tem de ser bem devagarinho, Amada,

que a vida é breve, e o amor mais breve ainda..

\section{De Natasha Felbx:}

\section{com a cabeça pousada}

nas pernas da avó

a saia de brocado

pinica a orelha

esquerda.

cantarola salmos e vai à caça

distraida.

o pente-fino é azul.

as varizes na panturrilha dela também.

os dias e a toalha de mesa.

o pente-fino

atravessa meus cabelos de diaba

as crianças dizem diaba

eu nunca digo.

um pouco amansados

(nào o suficiente)

com álcool e cravos

nada

enquanto a avó ajeita os óculos,

procura bichos em mim.

a mesma que estoura as lêndeas

as unhas imensas.

como se vingasse

suspeito

- que não caberia na casa
Para o primeiro amor, de Gessica com Gề

Não sei o que estou escrevendo

Năo sei nem mesmo o que estou dizendo

Acho que estou dando um aperitivo ao meu coraçăo

Que está cada vez mais te querendo

Ele grita te chamando

E palpita o tempo inteiro

Me sinto como uma agulha

Perdida num estaleiro

Pego o telefone e te ligo, sem te dizer meu nome.

Procuro algo, um motivo

A fome năo é de alimento

A fome năo tem sabor

A fome que eu sinto agora.

E a fome do teu amor.

Você năo sabe mais quem sou

Só sabe que eu era a șa vizinha

Queria tanto que vocè se lembrasse das mil e uma

cartinhas

Que eu jogava na sua garagem

Todo dia de manhãzinha

Nelas, frases de amor eu escrevia

Na esperança de que você lesse um dia

De que vocé conseguisse compreender

A intensidade da minha agonia,

De ter só um pouquinho de você.

De sentir ao menos uma vez.

Essa sua boca linda.

Esperando, sempre, que um dia vocề abrisse os

braços e dissesse:

Gé seja bem vinda!

* seja bem vinda ao meu coração,

A vitória da sua paixăo!"

Quem acredita sempre alcança

Quem acredita nunca cansa, nunca desiste.

Porque o amor (Fernando) é a melhor coisa que existe!

Para que te amem, de Ryane Leão

não te ensinam nada

sobre amor próprio

mas te dão uma lista

de como vocé deve agir

para que te amem

- como o machismo faz

\section{De mãe, de Conceição Evaristo}

o cuidado de minha poesia

aprendi foi de mãe,

mulher de pôr reparo nas coisas.

e de assuntar a vida.

A brandura de minha fala

na violência de meus ditos

ganhei de màe,

mulher prenhe de dizeres.

fecundados na boca do mundo.

Foi de màe todo o meu tesouro

veio dela todo o meu ganho

mulher sapiència, yabà

do fogo tirava água

do pranto criava consolo.

Foi de mãe esse meio riso

dado para esconder

alegria inteira

e essa fé desconfiada

pois, quando se anda descalço

cada dedo olha a estrada. 
Foi mãe que me descegou para os cantos milagreiros da vida apontando-me o fogo disfarçado em cinzas e a agulha do tempo movendo no palheiro. Foi mãe que me fez sentir

as flores amassadas debaixo das pedras os corpos vazios rente as calçadas e me ensinou,

insisto, foi ela

a fazer da palavra

artificio

arte e oficio

do meu canto

da minha fala.

\section{De Rupi Kaur}

o amor vai chegar

e quando o amor chegar

o amor vai te abraçar

- amor vai dizer o seu nome

e você vai derreter

só que as vezes

o amor vai te machucar mas

- amor nunca faz por mal

- amor não faz jogo

porque o amor sabe que a vida já é dificil o bastante

\section{De Rupi Kaur}

toda vez que você diz para sua fillha que grita com ela por amor

você a ensina a confundir

raiva com carinho

o que parece uma boa ideia

até que ela cresce

confiando em homens violento

porque eles ș̃o tão parecidos com vocề

- aos pais que têm filhos amor

a.mor

sm

1 Sentimento que leva uma pessoa a desejar o que se the afigura belo, digno ou grandioso.

2 Grande afeição que une uma pessoa a outra, ou a uma coisa, e que, quando de natureza seletiva e eletiva, é frequentemente acompanhada pela amizade e por afetos positivos, como a solicitude, a ternura, o zelo etc.; afeto, devoçăo.

3 Sentimento ardoroso ou passional de uma pessoa por outra, que se manifesta em forma de atraçäo física e näo implica, necessariamente, o empenho pessoal reciproco; atração que tem por base o desejo sexual.

4 Relação ou aventura amorosa; caso, namoro.

50 ato sexual: Faziam amor o tempo todo.

6 Sentimento efêmero $\mathrm{e}$ inconsequente; capricho: Seu amor ao cunhado durou apenas um verão.

7 Aventura amorosa; amores: Os amores da atriz eram públicos e notórios.

8 Tendência ou instinto que resulta em atração fisica e natural entre as outras espécies animais.

9 Apego a coisas ou a objetos inanimados e ideais que proporcionem prazer; entusiasmo, paixão: Amor aos livros, à justiça e ao bem.

10 Desejo intenso de possuir ou conseguir algo; ambição, cobiça, ganåncia: Tinha um amor exagerado à conquista de uma posição social de destaque.

11 Nas relaçōes interpessoais, afeição que decorre de amizade, admiração ou interesses comuns; benevolência, carinho, simpatia: Falava com amor dos professores que o haviam ajudado.

12 REL Sentimento de caridade e compaixão que liga uma pessoa a seus semelhantes e que decorre da ideia de que uma relação comum une Deus a todas as suas criaturas: Deixou como exemplo de vida $o$ amor pelos pobres.

13 Cuidado extremo; esmero, fidelidade, zelo: Esculpia com amor, sem pensar em dinheiro.

14 MIT Divindade que personifica o amor (como Cupido e Vênus). 150 objeto do amor, acepç̄es 1 a 7.

Fonte: http://michaelis, uol com. br/busca?r=0\& $t=0 \& t=0 \&$ palwra=amor

Data de submissão: 17/08/2020

Data de aceite: 04/10/2020 